\title{
The Exploration of Integrating Piano Teaching into Ideological and Political Education from the Perspective of Morality Building and People Cultivating
}

\author{
Tingting Rao \\ Yangtze University School of Art, Jingzhou, Hubei, China
}

\begin{abstract}
In the process of ideological and political education, ideological and political courses, as a hot topic, can promote the construction of modern ideological and political teaching systems. Mainly from the perspective of morality building and people cultivating, this article takes the piano course as the main research object, introduces in detail the connotation of the ideological and political curriculum, the internal connection between the ideological and political curriculum and the piano curriculum, and explores the ideological and political teaching methods in the piano curriculum, in order to give colleagues in the industry some reference.
\end{abstract}

Key words: morality building and people cultivating; ideological and political education; piano curriculum

\section{Introduction}

The Party Central Committee attaches great importance to the development of ideological and political education. Since the 18th National Congress of the Communist Party of China, General Secretary Xi has put forward the importance of ideological and political education in many conversations, and clearly pointed out that ideological and political education needs to put morality building and people cultivating in the first place. In traditional teaching, the ideological and political course as a teaching carrier has been difficult to meet the goals set by the current education. Therefore, it is necessary to continuously develop new ideological and political education resources, which has become a current focus. Especially for the teaching of piano professional courses, how to integrate ideological and political education throughout the teaching process to strengthen students' professional skills, train students' morality and ensure that piano professionals gradually grow into responsible and conscious high-quality talents, and enable them to actively provide services to the people in their work, and contribute to the country's sense of creativity and innovation. This has also become a goal that must be achieved in piano education and teaching.

\section{Piano Education Based on Ideological and Political Courses}

2.1 Connotation of ideological and political courses

As a popular vocabulary in current ideological and political education, ideological and political courses are mainly responsible for extending and expanding from traditional ideological and political courses to other courses when carrying out ideological and political education. In 2017, General Secretary Xi Jinping clearly stated in the national ideological and

Copyright (C) 2021 by author(s) and Frontier Scientific Research Publishing Inc.

This work is licensed under the Creative Commons Attribution International License (CC BY 4.0).

http://creativecommons.org/licenses/by/4.0/ 
political education work that it is necessary to ensure that the ideological and political theory courses and various courses are advanced simultaneously, and thus the efficiency of mutual coordination is formed. The development of the ideological and political courses is mainly based on the fundamental task of morality building and people cultivating, ensuring that the ideological and political courses and various courses are in the same direction, and continuously exerting the educational value of different ideological and political courses, and at the same time, it can also build a full and comprehensive lessons and the whole process of educating people. The emergence of ideological and political courses can effectively make up for the problems that occur in traditional ideological and political teaching, and enrich the ideological and political education positions, and constantly build a new era of ideological and political education system.

\subsection{The inner connection between ideological and political education and piano course}

Ideological and political courses are mainly based on the current development direction of ideological and political education. After being put forward, they have become important guiding opinions for driving the reform of ideological and political education. At present, colleges and universities have applied for multiple professional courses as pilot programs for the reform of ideological and political process, and the Shanghai area has achieved the most significant results, thus forming the Shanghai experience. In the process of opening the piano course, because of its close connection with ideological and political education, it has a unique advantage in the construction of ideological and political courses.

\section{The Construction Method of the Ideological and Political Education Teaching Route in the}

\section{Piano Course}

3.1 In-depth exploration of ideological and political elements

In the piano course, there is a strong interoperability and compatibility between the course content and ideological and political education, so it is necessary to tap the ideological and political elements to carry out teaching. The first is to start from the piano course and conduct in-depth exploration of ideological and political education. It can be found that ideological and political education is the prerequisite and basis for better development of piano ideological and political courses. For example, starting from the background of the time when the piano works are located, and at the same time continuously digging into the author's life story. Take Sang Tong's piano work In That Faraway Place as an example. This work is mainly shown by Chinese composers using a free and atonal creative mode. It shows the creator's high patriotism and the emotional ups and downs of grief and indignation. It is also a handed down work among the patriotic education works of our country. The second is to continuously explore its inner ideological and political elements in the theme song. In piano works, patriotic themes are very common, and they are also the most classic themes of national piano works. For example, the famous Chinese composer Wang Jianzhong adapted the piano music Liuyang River and Embroidered Golden Plaque adapted from the song of the Anti-Japanese War. These are famous works of patriotic themes in my country. Teachers need to dig deeper into the moral education elements in piano works, so that students can feel the national color in them, and at the same time can better achieve the goals of ideological and political education. The third is to continuously excavate ideological and political elements, melody, rhythm and other music content from the piano melody and rhythm, and use the emotion of piano works as sustenance. Teachers not only need to integrate the ideological and political education content into it, but also need to start from their own aesthetic point of view to better carry out teaching activities locally. For example, when teaching the Yellow River Piano Concerto, because the it is adapted from the national salvation song Yellow River Cantata during the Anti-Japanese War, it incorporates some ethnic elements such as boatman chants in the musical structure. At the same time, the Western classical piano concerto performance method is also used, especially in the last part of the music. The author uses a unique form of expression to integrate multiple songs such as Internationale, Dongfanghong, Defense of the Yellow River and so on. It strongly demonstrates the pride of the 
Chinese nation and the unyielding spirit of struggle.

\subsection{Focus on strengthening emotional experience}

The content of ideological and political education involved in the piano course is from a deep-level perspective, so there is a similarity between the two, and both focus on student development. But in the implementation process, there are corresponding differences. Current courses mostly start from students' perceptual thinking, while the development of ideological and political education chooses to start from students' rational thinking. The two have completely different effects. Therefore, adding ideological and political education to piano courses requires more attention to the emotional experience brought to students, so that students can be edified in the emotional experience of music. One is the need to subconsciously train students to have the ability to listen, so that students can actively perform during practice, listen to the various demonstrations of the teacher and various audio in the quyi works, and improve students' breath, phrases, melody, and rhythm during training, and so on, so that students can deeply experience the inner emotions that the work wants to express; the second is to strengthen communication and exchanges with teachers and students. Teachers need to attach great importance to the exchange activities between teachers and students, and regard ideological education as a key project for continuous communication between teachers and students. For example, when studying the patriotic subject of Defending the Yellow River, students should be guided to learn to discuss the spiritual power of piano works, and then strengthen students' ability to perceive independently. In the process of standardized training, the students' sense of autonomy is continuously improved, which lays a solid foundation for students to better carry out piano performance learning. In ideological and political courses, the relationship between ideological and political education and curriculum teaching should be continuously strengthened. Teachers need to actively cultivate students' ability to perceive works. This is also the focus of ideological and political teaching, and finally the emotions of students are sublimated. In the process of piano performance, it is necessary to use the heart, brain, hands, eyes and other methods to externalize the music, so that the audience can have emotional resonance during the listening process. Piano teachers also need to continuously inspire students to actively explore the value of music, so that students' emotions are sublimated.

\subsection{Guide students to learn to practice independently}

The value and significance of ideological and political education should be emphasized in piano courses. Taking the original task of the piano course as the main premise, and adding the ideological and political education teaching content involved in the piano course, the focus is to guide students to practice independently, and then continue to add ideological and political education content to it. First of all, in the process of independent practice, students need to cultivate the spirit of perseverance, because piano practice is an arduous and long-term task that requires students to have perseverance. Teachers need to combine the spirit of the Long March with students' piano practice, So that students can work hard to overcome various difficulties in learning with a high learning attitude and not afraid of difficulties, and ultimately improve students' learning effect; the second is to cultivate students' craftsmanship spirit. In the current professional teaching process, craftsmanship spirit is one of the main goals of ideological and political education. The craftsmanship spirit basically starts from the professional field and adds the spirit of excellence to it, and it is also good for professionalism and hard work. In the form of quality expression, teachers need to integrate the spirit of summer training and winter training with students' independent practice, so as to improve students' sense of urgency in learning, and strengthen students' practice effect, and finally can better realize the practice goal; the third is to exercise the good qualities of students in the process of independent practice. In the process of playing piano pieces, it puts forward higher requirements for students' performance skills, and also has the same requirements for students' psychological quality. Students need to have a good control of their performance skills to avoid making mistakes. If this happens, students' self-confidence will be affected. 
Teachers can quote Chairman Mao studying in downtown during his youth. The stories and experiences of the students educate students so that they can feel that Chairman Mao can study calmly under any difficult conditions, ensure that their mood is not disturbed by external factors, and cultivate students to have confidence and chic ability; the fourth is to cultivate students' aesthetic creativity in the process of independent practice. Playing and training piano works, as an important part of piano playing course, requires students to take the initiative to assume the important task of performance. In the process of the performance of the work, diversified elements of moral education are added to it, using advanced performance methods to cultivate the perseverance of students, and to form perseverance and courage. These have become some irreplaceable tasks in ideological and political teaching.

\subsection{Strengthening the construction of teaching staff as guarantee}

The integration of ideological and political education courses and piano courses can point out the correct development direction for the continuous expansion of piano courses, but it also makes piano teachers face greater pressure when teaching. Judging from the current piano course teaching situation, many teachers have solid professional qualities, but they have a low level of ideological and political theory, so it is difficult to take the initiative to take the responsibility of teaching ideological and political courses. Therefore, in the teaching process, the school should take the initiative to strengthen the construction of the teaching staff. First, adopt the concept of advancing with the times. This requires teachers to start from the current curriculum ideological and political concepts and combine them with the overall development needs of students. Recognize the principles in the piano teaching process, take the piano curriculum as the main course of students' learning, and integrate ideological and political education into the piano teaching, and continue to expand the boundaries of piano teaching; second, continue to strengthen the intensity of educational theory learning in the new period. In the process of ideological and political education in piano courses, teachers need to have a higher level of ideological and political theory. And they need to combine their own growth with professional development and other key content, strengthen their own learning of classic theories, such as Deng Xiaoping Theory, Mao Zedong Thought, MarxismLeninism, etc., and also need to conduct in-depth exploration of the latest theoretical results, such as the socialism with Chinese characteristics proposed by Xi Jinping, which ensures that one's own theoretical accomplishment is improved, and lays a good foundation for later piano teaching.

\section{Conclusions}

In summary, in our country's teaching system, ideological and political education, as an important part of it, is in an irreplaceable position in the teaching process of students' ideology, morality and political theory. Combining piano courses with ideological and political education. On the one hand, because the two have the same educational objects, whether it is ideological and political education or piano courses, teachers need to guide students, so as to continuously promote the allround development of students, ensure the consistency of educational tasks and educational objects, and lay a solid foundation for building a harmonious relationship between the two. On the other hand, it is necessary to ensure that there is a common value pursuit between the two. Piano courses are listed as the category of art education, and aesthetic education is the core. Truth is the foundation of beauty, and goodness is the sublimation of beauty. Therefore, the continuous integration of piano teaching and ideological and political education, enriching the content of piano teaching, and proposing new methods of piano teaching are also conducive to cultivating students' comprehensive qualities.

\section{Conflicts of Interest}

The author declares no conflicts of interest regarding the publication of this paper.

\section{References}

[1] Lin J.J. (2020). Research on the Integration of Moral Education and College Piano Teaching from the Perspective 
of Ideological and Political. Home Drama, (19): 73.

[2] Lv J.H. (2020). Research on the Way of Integration of Piano Course and Course Ideology. Song of the Yellow River, (10): 88+90.

[3] Wang C.C. (2020). Discussion on the Teaching Strategy of Ideological and Political Education in Piano Course in College. China Rural Education, (14): 2-3.

[4] Dai Y. (2020). Analysis of the Integration Measures of Moral Education and University Piano Teaching from the Perspective of "Ideological and Political". Northern Music, (05): 132-133. 